\title{
The Relationship of Executive Function and Reading Comprehension Ability in School-Aged Children with and without Vocabulary Delay
}

\author{
Jieun Kang ${ }^{1}$, Hyojung Kwak ${ }^{1}$, Hyejo Kim ${ }^{1}$, Minah Yoo ${ }^{1}$, Dongsun Yim ${ }^{2}$ \\ M. A. Student, Department of Communication Disorders, Ewha Womans University, Seoul, Korea ${ }^{1}$ \\ Professor, Department of Communication Disorders, Ewha Womans University, Seoul, Korea ${ }^{2}$ \\ 학령기 어휘지연 아동과 일반아동의 집행기능과 읽기이해 비교 및 \\ 상관관계 연구 \\ 강지은 ${ }^{1}$, 곽효정 ${ }^{1}$, 김혜조 ${ }^{1}$, 유민아 ${ }^{1}$, 임동선 ${ }^{2}$ \\ 이화여자대학교 대학원 언어병리학과 석사과정생 ${ }^{1}$ 이화여자대학교 대학원 언어병리학과 교수 ${ }^{2}$
}

\begin{abstract}
Objectives: A child's reading ability is influenced by Execution Functions (EFs) adjusting and managing linguistic knowledge as well as linguistic knowledge to the desired situation. The study examined the relationship of EFs (working memory, inhibition and shifting) and reading comprehension in children with and without Vocabulary Delay (VD).

Methods: Nineteen children 9-to-12-years-old with VD and eighteen children with Typically Developing (TD) participated in this study. Participants' EFs were assessed by the Nonword Repetition task (NWR) for working memory, the Stop Signal Task (SST) for inhibition, the Dimensional Change Card Sort (DCCS) for shifting. Additionally, story reading comprehension ability in children was examined.

Results: VD group showed statistically significantly lower performance in NWR and reading tasks, respectively, compared to TD group. Pearson's correlation coefficient showed that reading skills were positively and significantly correlated with working memory in both the groups.

Conclusion: The NWR task which tap linguistic working memory reflects the acceptance and acquisition power of the combination of the various newly encountered phonemes and phonemes. This suggests that linguistic working memory may have an important effect on reading comprehension in the early stages of language and vocabulary acquisition.
\end{abstract}

Keywords: school-aged children, executive function, working memory, inhibition, shifting, reading comprehension, vocabulary delay

\section{Introduction}

읽기는 낱말재인(word recognition)과 읽기이해(reading comprehension)를 통해 이루어진다(Chung, 2011). 낱말재인은 시 각적으로 인식된 단어와 분절적 자질이 같은 낱말을 말소리로

Corresponding Author: Dongsun Yim, Professor, Department of Communication Disorders, Ewha Womans University, 52 Ewhayeodae-gil, Seodaemun-gu, Seoul 03760, Korea

E-mail: sunyim@ewha.ac.kr
변환하고, 그에 해당하는 어휘를 자신의 심성어휘집에서 표상 하여 의미와 연결하는 과정이다(J. L. Kim, Kang, \& Lee, 2018). 이 과정은 읽기의 초기 단계에서 중요한 요인으로 밝혀졌으며 (Catts, 2005), 낱말재인을 통해 글의 내용을 구문적 및 의미적 단 서에 따라 처리하여 내용을 파악하는 것이 읽기이해이다(Catts,

(C)The Korean Association of Child Studies

This is an Open Access article distributed under the terms of the Creative Commons Attribution Non-Commercial License (http:// creativecommons.org/licenses/by-nc/4.0) which permits unrestricted noncommercial use, distribution, and reproduction in any medium, provided the original work is properly cited. 
2009). 읽기 과정에서 어휘력은 아동의 낱말재인 능력과 읽기이 해력에 큰 영향을 미친다(A. H. Kim, 2013; Ouellette, 2006; Yoon, 2019). 즉, 어휘 수준이 높은 아동은 또래보다 더 높은 낱말재인 능력과 읽기이해력을 보이며, 어휘 수준이 낮은 아동은 배경지 식이 부족하고 텍스트 구조를 파악하지 못하여 읽기에 어려움 을 보이게 된다. 그러나 읽기이해에는 낱말재인 뿐만 아니라 어 휘력, 배경지식, 추론능력 등과 같은 다양한 요인이 영향을 미치 며(Vaughn, Gersten, \& Chardet, 2000), 연령이 증가함에 따라 읽 기 지문의 길이와 수준이 높아지므로 형태적, 통사적, 의미적 영 역을 포함하는 전반적인 언어 능력과 집행기능의 처리가 기반 이 된 높은 수준의 인지 과정이 필수적이다(Dehaene, 2009).

집행기능(Executive Function [EF])은 개념을 형성하여 사 고를 조직하고 행동이나 생각을 통제하는 데 필요한 상위 수 준의 인지 메커니즘으로서(Diamond, 2013) 그 하위 요소들은 단어 회상과 같은 명시적인 언어 처리를 실행할 뿐만 아니라, 새로운 어휘를 습득하고 처리하는 과정을 포함한 다양한 언 어학습 상황에서 중요한 기능을 한다(Hughes, 1998; Marton, Campanelli, Eichorn, Scheuer, \& Yoon, 2014; Mazuka, Jincho, \& Oishi, 2009). 또한, 기본적인 의사소통과 학업을 가능하게 함 으로써 다른 교과의 효율적인 학습을 가능하게 하므로 아동의 인지 발달과 큰 관련이 있다(Stanovich, 1986). 집행기능의 주 요 통합적 모델은 작업기억(working memory), 억제(inhibition), 전환(shifting)의 3가지 능력을 포함한다(Miyake et al., 2000).

첫째, 작업기억(working memory)은 외부에서 들어오는 새 로운 정보를 일시적으로 보유하여 조작하는 능력을 의미한다 (Diamond, 2013). 어휘발달지연 아동은 빠르게 들어오는 음 운 정보를 짧은 순간에 구어로 저장하고 조작해야 하는 음운 및 구어 작업기억 과제에서 어려움을 보인다(Alt, 2011; Henry, Messer, \& Nash, 2012; Montgomery, 2002). 특히 낮선 자극 정 보가 들어오거나, 자극의 길이가 증가할 때 수행이 급격히 저 하되고 이러한 결함이 새로운 어휘 습득 및 언어학습에 영향 을 미치게 된다(Alt, 2011; Montgomery \& Windsor, 2007; Yang, Yim, Kim, \& Han, 2013). 작업기억은 읽기이해와도 밀접한 관 련이 있다. Just와 Carpenter (1992)는 개인의 작업기억 용량 차 이가 읽기이해 차이를 일으킨다고 주장하였으며, 실제로 읽 기이해 과제에서 어려움을 겪는 사람들은 작업기억 과제 수 행력이 낮은 것으로 나타났다(Carretti et al., 2009). 또한, 선행 연구에서 작업기억이 10-12세 학령기 아동의 읽기 이해에 영 향을 미치는 요인임을 밝혀냄으로써 학령기 아동의 읽기이 해력과 작업기억 간 높은 관련성을 시사하였다(Borella \& De Ribaupierre, 2014). 이처럼 작업기억은 어휘력, 읽기이해력과
높은 관련이 있다. 그러나 학령기 아동은 학령전기 아동보다 어휘력의 중요성이 간과되어 어휘지연 아동을 대상으로 한 연 구가 매우 제한적이며, 학령기 어휘지연 아동의 작업기억과 읽기이해력을 연구하여 어휘력, 작업기억, 읽기이해 간의 상 호관계를 밝힐 필요가 있다. Baddeley (1986)의 작업기억 모델 에서는 숫자 바로 따라말하기(forward digit recall), 비단어 따라 말하기(nonword repetition) 과제 등을 통하여 음운회로의 기 능을 평가하였으며, 숫자 거꾸로 따라말하기(backward digit recall), 읽기 폭 과제(reading span task) 등을 통하여 작업기억 을 평가하였다. 비단어 따라말하기는 낮선 소리 패턴을 듣고 즉각 따라 말하는 과제로 여러 단계의 지각, 인지, 언어 처리 과정 및 말 산출 능력이 필요하며, 특히 작업기억력을 간편하 고 민감하게 측정할 수 있다는 연구 결과에 따라(Dollaghan \& Campbell, 1998; Gathercole \& Baddeley, 1990) 본 연구에서는 비단어 따라말하기 과제를 작업기억 측정 도구로 활용하였다.

둘째, 억제(inhibition)는 정보처리 과정에서 관련성이 없는 정보에 대해서 스스로 제어하는 능력을 의미하는데, 억제는 중 의적 단어 및 구절로 인한 모호한 표현을 잘못 해석하는 것을 막을 수 있으므로 언어 능력과 매우 높은 상관이 있으며, 읽기 에 어려움을 겪는 아동은 또래 아동보다 관련 없는 정보를 억 제하는 데 어려움이 있다(Gernsbacher \& Faust, 1991). 또한, 언 어 처리 과정 중 불필요한 정보를 억제하기 위해 필수적인 요 소이며, 목표 어휘를 학습할 때 중요한 역할을 한다(Wilson \& Kipp, 1998). 이에 따라 Yang과 Yim (2018)은 주의력 결핍 과잉 행동 장애 아동을 대상으로 억제와 어휘력, 억제와 읽기이해력 간의 관련성을 밝혔으며, Yang, Yim과 Bae (2015)의 연구에서도 단순언어장애 아동의 어휘 학습 능력을 예측할 수 있는 중요한 요인 또한 억제 능력인 것으로 보고하였다. 그러나 억제와 어 휘력, 읽기이해력 세 요소 간의 연관성을 밝혀낸 연구는 진행 되지 않아 본 연구에서는 학령기 일반아동과 어휘발달지연 아 동을 대상으로 세 요소 간의 관련성을 밝혀내고자 하였다.

셋째, 전환(shifting)은 한 영역에서 과제에 대한 주의를 다 른 영역으로 바꾸는 것이며, 이전에 제시되었던 규칙을 억제 하고 새로운 규칙으로 이동한 뒤 그 규칙에 대한 주의를 잃지 않는 것이다(Diamond, 2006; Garon, Bryson, \& Smith, 2008). 어휘발달지연 아동은 이러한 전환 능력에 어려움을 보이며, 또래 일반아동과 비교하면 상대적으로 목표 자극과 관련 없는 주변 자극을 억제하고 목표 자극만 분류하여 집중하는 것에 어려움을 보인다(Marton et al., 2014). 이러한 연구 결과를 통 하여 아동의 어휘력과 전환 간의 관련성을 예측할 수 있다. 또 한, 전환은 개인이 음성적 정보와 의미적 정보를 동시에 처리 
하고, 정보를 회상하거나 읽기 목표와 난이도에 따른 읽기 전 략을 스스로 조정할 수 있도록 해주기 때문에 읽기이해에 영 향을 미친다(Nouwens, Groen, \& Verhoeven, 2016). 읽기에서 어려움을 겪는 아동은 또래 아동보다 학습규칙이나 주의를 전환하는 데 결함이 있는 것으로 밝혀졌다(Stoet, Markey, \& López, 2007). 반면에 전환 능력은 성인기까지 발달하므로 아 동의 경우 전환과 읽기 간 관계를 명확히 밝힐 수 없다는 연 구 결과도 있다(Engel de Abreu, Puglisi, Cruz-Santos, Befi-Lopes, $\&$ Martin, 2014). 이처럼 전환과 읽기 간의 관련성을 주장하는 학자들의 비일관적인 결과로 인하여 전환과 읽기 간의 관계 를 명확히 하기 위한 연구가 필요하다. 전환은 가장 대표적인 Stroop 과제(Klein, 1964)를 통해 평가할 수 있으나, 전환에 대 한 중요성이 부각되지 않아 작업기억보다 과제가 한정적이다. 따라서 새로운 전환 과제를 사용하여 연구를 진행한다면 과제 를 보다 다양화할 수 있을 것이다.

이처럼 다양한 연구 결과를 통하여 집행기능과 읽기이해 간 의 관련성과 집행기능과 어휘력 간의 관련성이 밝혀졌다. 그러 나 전환과 읽기 능력 간의 관련성을 주장한 학자들과 대립하 는 학자들의 의견이 밝혀져 비일관적인 연구 결과로 상호 관련 성을 해석하는 데 어려움이 따른다. 또한, 다양한 언어장애 집 단의 집행기능과 언어 능력 간의 관련성에 관한 연구는 활발하 게 진행되었던 것과 달리, 어휘발달지연 아동의 집행기능과 언 어 능력과의 관계를 밝혀내고자 하는 연구는 여전히 제한적이 다. 그러므로 본 연구는 일반아동과 어휘발달지연 아동을 대상 으로 읽기이해 정도를 확인하여 언어 능력 간의 관련성을 밝혀 내고, 집행기능의 하위 요소와의 관계를 통하여 학령기 아동의 효과적인 중재 방안 모색을 위한 기초자료가 되고자 한다. 따 라서 본 연구에서는 학령기 일반아동과 어휘발달지연 아동 집 단을 대상으로 집행능력의 하위 요소(작업기억, 억제, 전환)과 어휘력, 읽기이해 간의 관련성을 살펴보고자 하였다.

이에 따른 본 연구의 가설은 다음과 같다. 학령기 일반아동이 어휘발달지연 아동보다 집행기능 과제에서 높은 수행력을 보인 다면, 읽기이해 과제에서도 높은 수행을 보일 것이다. 또한, 아동 의 집행기능(작업기억, 억제, 전환) 하위 요소는 각각 읽기이해력 과 유의한 상관을 보일 것이다. 학령기 일반아동과 어휘발달지 연 아동을 대상으로 한 본 연구의 질문은 다음과 같다.

\section{연구문제 1}

학령기 일반아동과 어휘발달지연 아동은 집행기능(작업기억, 억제, 전환) 과제에 따라 집단 간 유의한 차이를 보이는가?

\section{연구문제 2}

학령기 일반아동과 어휘발달지연 아동은 읽기이해 과제에서 집단 간 유의한 차이를 보이는가?

\section{연구문제 3}

학령기 일반아동과 어휘발달지연 아동 각 집단 내에서 집행 기능(작업기억, 억제, 전환)과 읽기이해력 간 유의한 상관을 보이는가?

\section{Methods}

\section{연구 대상}

본 연구의 대상은 경기 지역에 거주하는 만 9세 12세(초등학 교 4-6학년)로 남아 61명, 여아 67명으로 총 128 명의 대상자 평가 후, 아래의 선별 조건에 따라 어휘발달지연 19 명, 일반아 동 18 명 총 37 명을 선정하였다. 연구에 참여한 어휘발달지연 아동은 다음과 같은 기준으로 선정하였다. (1) 부모 또는 교사 보고에 따라 지능발달 및 언어발달 수준이 정상이고, 기타 감 각, 정서상에 이상이 없으며, (2) 검사자가 수용 및 표현 어휘 력 검사(Receptive \& Expressive Vocabulary Test [REVT]; Y. Kim, Hong, Kim, Jang, \& Lee, 2009)를 실시한 결과, 수용어휘력 점 수가 - $1.25 S D$ 이하인 아동을 대상으로 하였다. 일반아동은 (1) 부모 또는 교사 보고에 의하면 지능발달 및 언어발달 수준이 정상이며, 기타 감각, 정서상에 이상이 없고, (2) 검사자에 의 해 수용 및 표현 어휘력 검사(REVT; Y. Kim et al., 2009)의 수용 어휘력 점수가 평균 이상인 아동을 대상으로 어휘발달지연 아 동의 성별과 생활 연령을 고려하여 선정하였다. 3 가지 집행기 능 검사를 모두 수행하지 못하거나, 읽기이해 과제에 임하지 않겠다는 의사를 보인 아동은 연구대상에서 제외되었다.

\section{Methods}

\section{집행기능 과제}

\section{작업기억 과제: 비단어 따라말하기(nonword repetition task)}

본 과제는 구어적 작업기억 능력 측정을 위해 선행연구(Yang $\&$ Yim, 2018)의 비단어 따라말하기 과제를 사용하였다. 해당 
과제는 기존 어휘 지식의 부족으로 어휘발달지연 아동에게 발 생할 수 있는 과제 수행상의 잠재적 불이익을 최소화하기 위 하여 기존 유의미 단어와 유사성이 낮은 20 개의 비단어로 구 성되어 있다. 비단어는 각각 음절마다 되도록 다양한 음소를 포함하도록 하였고, 조음 위치상 양순, 치조, 경구개, 연구개음 이 균등하게 분포하도록 제작되었다(H. J. Lee, 2010).

검사는 연구자가 소음이 없는 조용한 장소에서 아동과 일 대일로 마주 보고 착석하여 진행되었다. 검사자는 아동에게 비단어 목표 자극을 육성을 통해 들려주고, 아동이 즉시 반복 하여 따라 말하도록 하였다. 비단어는 2음절 조건 4 개, 3 음절 조건 4개, 4음절 조건 4개, 5음절 조건 4개, 6음절 조건 4개, 총 20 개가 길이순으로 제시되었다. 아동이 과제 수행방법을 정 확히 이해했는지 확인하기 위해 연습 문항을 실시하였으며, 아동이 과제 수행방법을 이해한 것을 확인한 후, 본 문항을 실 시하였다.

비단어 따라말하기 과제는 단어 단위보다 음절 단위 점수 가 어휘 및 읽기 수행 사이의 관련성을 보여주기에 더 민감한 지표로 나타난 연구 결과(Hwang, 2014)에 근거하여 정확하게 산출한 음절의 비율에 따라 정반응률(\%)을 계산하였다. 전체 문항의 총 음절수는 91음절로 아동이 음절 내 모든 음소를 정 확히 따라 말할 경우(1점)을 부과하고, 음소를 하나라도 부정 확하게 말할 경우(0점)으로 처리하여 총점 기록 후 정반응률 (\%)을 계산하였다.

\section{억제 과제: 정지신호과제(stop signal task)}

본 과제는 아동의 억제 능력 측정을 위해 선행연구(Yang \& Yim, 2018)의 정지신호과제를 사용하였다. 이 과제는 목표 자 극이 모니터 중앙에 나타나면 일치하는 색깔의 버튼을 누르 고, 비목표 자극이 화면에 나타나면 버튼을 누르고 싶은 행동 을 억제해야 한다. 화면에 제시되는 시각적 자극으로는 빨간 불, 초록불 그리고 검정색 정지 표식이 있다. 제시된 네모 칸 안에 빨간불이 들어오면 빨간색 버튼을 누르고(go), 초록불 이 들어오면 초록색 버튼을 누르도록 한다(go). 그러나 검정 색 정지 표식이 나온 직후 네모 칸 안에 불이 들어오면 정지 신호(stop)로 인식하여 어떤 색깔의 불이 들어오더라도 버튼 누르는 행동을 멈추어야 한다. 이 과제의 핵심은 대상 아동이 STOP의 신호를 인식하여 버튼 누르는 행동을 억제하는 것이 다. 본 과제에서 제시되는 $\mathrm{GO}$ 의 자극은 81 개, STOP의 자극은 19 개로 총 100 개의 자극으로 구성되었다. 모든 자극은 $500 \mathrm{~ms}$ 동안 일정하게 제시되며, 각 자극 간 간격은 $1,500 \mathrm{~ms}$ 이다.
검사자는 아동의 손잡이를 고려하여 키보드 정중앙에 편 한 손을 올려두게 하였고, 준비 자세를 설명하였다. 화면에 제 시된 두 개의 네모 칸 중 빨간불이 들어오면 노트북 키보드의 정중앙에서 왼쪽( $\mathrm{Z}$ 버튼)에 부착된 빨간색 버튼, 초록불이 들 어오면 노트북 키보드의 정중앙에서 오른쪽(/ 버튼)에 부착된 초록색 버튼을 누르도록 하였고, 검정색 정지 표식이 나온 뒤 에는 버튼을 누르면 안 된다는 규칙을 설명하였다. 전환 과제 와 마찬가지로 손의 위치는 반응속도와 관련이 있으므로 버튼 을 누른 후, 반드시 준비 자세로 돌아가도록 하였다. 사전에 충 분한 연습시간을 제공하였으며, 아동이 과제 수행방법에 대해 숙지하였을 때 본 문항을 실시하였다. SST의 정확도와 반응속 도는 E-Prime 2.0 (Psychology Software Tools Inc., Pittsburgh, PA) 의 소프트웨어를 통해 기록되었다.

\section{전환 과제: 차원전환카드분류과제(dimensional change card sort task)}

본 과제는 아동의 전환 능력 측정을 위해 선행연구(Yang \& Yim, 2018)의 차원전환카드분류과제를 사용하였다. 이 과제 는 크게 기본단계와 심화단계로 나뉘며, 기본단계 내에서도 전환 이전(pre-shifting) 단계와 전환 이후(post-shifting) 단계로 나뉜다. 기본단계(전환 이전 및 전환 이후)는 각각 6개의 문항 씩 총 12 문항, 심화단계는 12 문항으로 구성되어 있다. 대상 아 동은 단계마다 다르게 적용되는 규칙을 빠르게 이해하고 적응 하여 버튼을 눌러야 한다. 본 과제에 사용된 총 4 가지의 그림 자극은 빨간 토끼, 초록 토끼, 빨간 배, 초록 배로 구성되었으 며, 컴퓨터 화면의 중앙에 1 개의 목표 자극이 제시되고 2 개의 보기 자극의 양옆에 제시된다.

기본단계(전환 이전)의 6 문항은 '색깔 게임'을 수행하는 것 으로, 자극의 모양과 관계없이 모니터 중앙에 나타난 목표 자 극과 동일한 색깔의 자극을 2 개의 보기 자극 중 선택한다. 기본 단계(전환 이후)의 6 문항에서는 '모양 게임'을 수행하는 것으 로, 자극의 색깔과 관계없이 모니터 중앙에 나타난 목표 자극 과 같은 모양의 자극을 2 개의 보기 자극 중 선택한다. 즉, 처음 시작 단계에서는 목표 자극과 동일한 색깔을 찾아야 하는 색 깔 게임으로 시작되지만, 중간에 규칙이 바뀌면서 목표 자극과 같은 모양을 찾는 모양 게임을 수행해야만 한다. 이 과정을 통 해 대상 아동이 변화된 규칙에 적응하여 각 단계에서 요구되는 수행을 정확하게 해내는지를 확인할 수 있다. 마지막으로 심 화단계에서는 기본단계의 색깔 게임과 모양 게임 2 가지 규칙 에 검정색 테두리 조건이 추가된다. 목표 자극 주위에 검정색 
테두리가 있으면 색깔게임을 수행해야 하고, 목표 자극 주위에 검정색 테두리가 없으면 모양 게임을 수행해야 한다. 이러한 과제 수행을 통해 아동의 전환 능력을 살펴볼 수 있다.

검사자는 아동의 손잡이를 고려하여 키보드 정중앙에 편한 손을 올려두게 하였고, 준비 자세를 설명하였다. 제시되는 보 기 자극 중 왼쪽 자극이 맞으면 노트북 키보드의 정중앙에서 왼쪽( $\mathrm{Z}$ 버튼)에 부착된 빨간색 버튼을 누르게 하고, 보기 자극 중 오른쪽 자극이 맞으면 노트북 키보드의 정중앙에서 오른쪽 (/ 버튼)에 부착된 초록색 버튼을 누르게 하였다. 손의 위치는 반응속도와 관련이 있으므로 버튼을 누른 후에는 반드시 준비 자세로 돌아가도록 하였다. 사전에 충분한 연습시간을 제공 하였으며, 아동이 과제 수행방법에 대해 숙지하였을 때 본 문 항을 실시하였다. DCCS의 정확도와 반응속도는 E-Prime 2.0 (Psychology Software Tools Inc., Pittsburgh, PA)의 소프트웨어를 통해 기록되었다.

읽기이해 과제: 나의 가장 친한 친구 미호, 애완 동물과 함께 등교하는 날의 재앙

본 과제의 읽기 지문은 내용 친숙도를 최소화하기 위해 국외 읽기 자료에서 지문 두 개를 발췌하여 연구자가 연구 목적에 맞게 번역 및 수정하였다. 두 개의 읽기 지문은 맥락 단서를 적 절히 이용하여 추론할 수 있도록 등장인물, 배경, 등장인물이 처해 있는 상황과 이야기 구조를 잘 갖추고 있는 이야기로 선 정되었다. 또한, 연구 대상인 초등학교 고학년 아동이 이해하 기에 큰 어려움이 없는 어휘를 사용하여 제작하였다. 석사 과 정 연구원 4 인과 1 급 언어재활사 2 인이 읽기 지문과 읽기이해 질문이 실험에 적합한지 검토하였다.

검사에 사용되는 읽기 지문 및 질문 내용이 대상 아동에게 적절한지 확인하기 위해 예비 실험을 시행하였다. 초등학교 4 학년 아동 30명, 5학년 아동 30명, 6학년 아동 30명 총 90명을 대상으로 예비 실험을 진행하였다. 질문지의 10 번 문항에 어 려움 정도를 10 점 척도로 표시하게 하여 난이도를 확인하였 고, 대부분 아동이 3-4점에 표시하였다. 또한, 질문이 모호하 거나 표현이 어색한 지문 및 문항은 수정하여 사용하였다.

검사자는 연구대상자에게 7분 동안 읽기 지문을 충분히 숙 지할 수 있도록 한 뒤, 읽기 지문을 소거하였다. 이후 읽기 지 문에 대한 문제를 풀 수 있는 시간을 제공하였으며, 사전 실험 을 통해 문제를 풀 수 있는 시간은 7분으로 제한하였다. 질문 지를 수집한 후에는 연구원 1명이 채점을 하였으며, 이후 다 른 연구원 3 명이 검토하였다. 각 질문에 대한 답은 아동이 질
문에 맞는 충분한 답을 작성한 경우(2점), 맥락은 맞으나 불충 분한 답을 한 경우(1점), 답하지 못하거나 엉뚱한 답을 작성한 경우(0점)으로 채점하였다. 읽기이해를 확인하기 위한 질문은 지문마다 사실적 정보 유형, 텍스트 연결 추론 유형, 빠진 정 보 추론 유형 각각 3 문항씩 총 9문항으로 제작되었고, 문항당 2점을 만점 기준으로 하여 지문 당 총 점수는 18 점이다. 결과 산출 시, 두 지문의 합산 점수를 사용하였다. 본 연구에서 사용 된 읽기 지문과 질문지는 Appendix 1에 제시하였다.

\section{연구 절차}

본 연구는 예비 실험 과정을 거친 뒤 경기도에 있는 한 초등학 교에서 $4,5,6$ 학년 아동을 대상으로 본 실험을 하였다. 연구에 적합한 대상자를 선별하기 위해 수용·표현어휘력검사(REVT; Y. Kim et al., 2009)를 실시하였으며, 소음이 없는 독립된 공간 에서 집행기능 과제와 읽기이해 과제를 차례로 실시하였다. 선별검사와 작업기억 과제는 아동과 연구자가 $1: 1$ 로 마주한 상태에서 실시되었으며 읽기이해 과제는 연구자의 감독 하에 9-10명씩 과제를 실시하였다. 교내 정규 수업으로 인해 검사 시간 부족 혹은 조퇴 등의 사유로 부득이하게 3가지 집행기능 검사를 모두 수행하지 못한 경우 82명, 읽기이해 과제에 임하 지 않겠다는 의사를 보인 아동 9명은 연구대상에서 제외되어 128 명 중 37 명의 데이터 값만 최종 분석하였다.

\section{자료 분석}

본 연구의 통계적 분석은 SPSS 24 (IBM Co., Armonk, NY)을 사용하였다. 먼저, 어휘발달지연 아동 집단과 일반아동 집단 간 집행기능의 하위요소별(작업기억, 억제, 전환) 수행 과제와 읽기이해 과제 수행력을 비교하기 위해 일원 배치 분산분석 (one-way ANOVA)을 하였다. 또한, 각 집단 내에서 집행기능 의 하위 요소들과 읽기이해 간 상관을 확인하기 위해 Pearson 상관분석을 실시하였다.

\section{Results}

\section{집행기능(작업기억, 억제, 전환)에서 집단 간 수행력 차이}

집단 간 집행기능(작업기억, 억제, 전환) 과제 수행에 대한 기 
Table 1

Descriptive statistics of Executive Function

\begin{tabular}{lcccc}
\hline & \multicolumn{2}{c}{ TD $(N=18)$} & \multicolumn{2}{c}{ VD $(N=19)$} \\
\cline { 2 - 5 } & $M$ & $S D$ & $M$ & $S D$ \\
\hline NWR & 96.11 & 3.394 & 89.58 & 4.388 \\
SST & 60.39 & 4.779 & 58.63 & 6.130 \\
DCCS & 97.04 & 9.468 & 81.34 & 8.679 \\
\hline
\end{tabular}

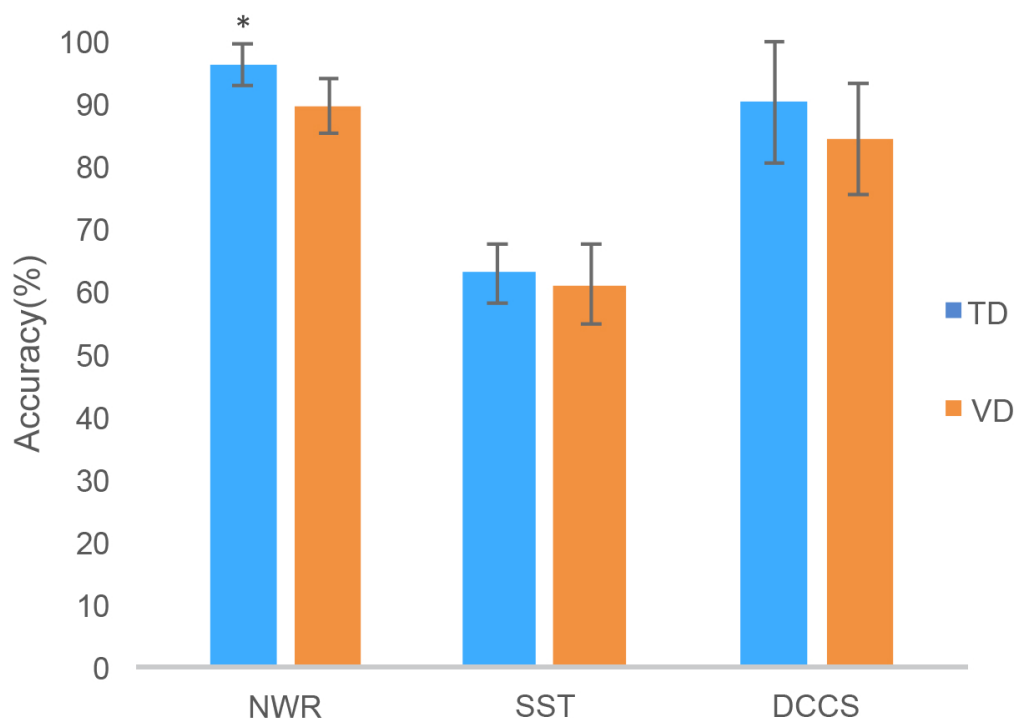

Figure 1. Comparing accuracy between TD and VD groups on NWR, SST, and DCCS.

${ }^{*} p<.05$.

술통계는 Table 1에 제시하였다. 두 집단 간 작업기억 과제 수 행력을 비교한 결과, 집단 간 차이가 통계적으로 유의하였다 $(F(1,35)=25.450, p<.05)$. 즉, 일반아동 집단 $(M=96.11, S D=$ $3.394)$ 이 어휘발달지연 아동 집단 $(M=89.58, S D=4.388)$ 보다 과제 수행력이 유의하게 높은 것으로 나타났다. 억제 과제에 서는 두 집단 간 차이가 통계적으로 유의하지 않았다. 전환 과 제에서도 두 집단 간 차이가 통계적으로 유의하지 않았다.

\section{읽기이해에서 집단 간 수행력 차이}

집단 간 읽기이해 과제 수행에 대한 기술통계는 Table 2에 제 시하였다. 두 집단 간 읽기이해 과제 수행력을 비교한 결과, 집단 간 차이가 통계적으로 유의하였다 $(F(1,35)=4.319, p<$ $.05)$. 따라서 일반아동 집단 $(M=96.11, S D=3.394)$ 이 어휘발 달지연 아동 집단 $(M=89.58, S D=4.388)$ 보다 과제 수행력이 유의하게 높은 것으로 나타났다. 두 집단 간 읽기이해 과제 수
행력을 Figure 2에 제시하였다.

\section{집단 내 변인 간 상관관계}

\section{일반아동 집단}

일반아동 집단의 집행기능 하위영역(작업기억, 억제, 전환), 읽기이해 간의 상관관계를 확인하기 위해 Pearson 상관계수를 산출하였다. 결과는 Table 3 과 같다.

일반아동 집단의 집행기능 하위 요소와 읽기이해 간의 상 관관계를 분석한 결과, 유의한 상관관계가 나타나지 않았다.

\section{어휘발달지연 아동 집단}

어휘발달지연 아동 집단의 집행기능 하위영역(작업기억, 억 제, 전환), 읽기이해 간의 상관관계를 확인하기 위해 Pearson 
Table 2

Descriptive statistics of Reading Comprehension

\begin{tabular}{lccccc}
\hline & \multicolumn{3}{c}{ TD $(N=18)$} & \multicolumn{2}{c}{ VD $(N=19)$} \\
\cline { 2 - 5 } & $M$ & $S D$ & $M$ & $S D$ \\
\hline Reading comprehension & 96.11 & 3.394 & 89.58 & 4.388 \\
\hline
\end{tabular}

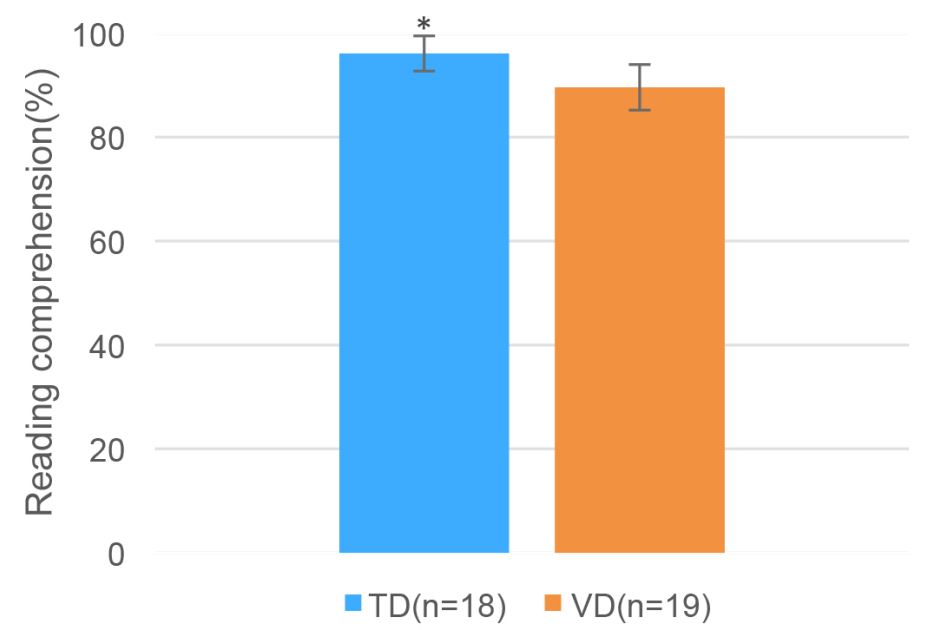

Figure 2. Comparing accuracy between TD and VD groups on reading comprehension task.

${ }^{*} p<.05$.

Table 3

Correlation Coefficients among NWR, SST, and DCCS in children with Typical Development

\begin{tabular}{|c|c|c|c|c|}
\hline & 1 & 2 & 3 & 4 \\
\hline Working memory & - & & & \\
\hline Inhibition & -.025 & - & & \\
\hline Reading comprehension & .444 & .008 & .009 & - \\
\hline
\end{tabular}

Table 4

Correlation Coefficient among NWR, SST, and DCCS in children with Vocabulary Delay

\begin{tabular}{lccc}
\hline & 1 & 2 & 3 \\
\hline Working memory & - & & \\
Inhibition & .082 & - & - \\
Shifting & -.265 & -.035 & -.187 \\
Reading comprehension & $.559^{*}$ & -.111 & - \\
\hline
\end{tabular}

상관계수를 산출하였다. 결과는 Table 4와 같다.

어휘발달지연 아동 집단의 집행기능 하위 요소와 읽기이해 간의 상관관계를 분석한 결과, 읽기이해는 작업기억 과제와 통계적으로 유의한 상관을 보였다 $(r=.559, p<.05)$. 그러나 다 른 변인 간의 유의한 상관관계는 나타나지 않았다.

\section{Discussion}

본 연구는 학령기 일반아동과 어휘발달지연 아동 집단을 대 상으로 집행기능(작업기억, 억제, 전환)과 읽기이해 간 관계를 살펴보고자 하였다. 집행기능의 하위 요소 능력을 측정할 수 
있는 과제를 사용하여 두 집단 간 차이를 비교하고, 각 집단 내 에서 읽기이해력과 관련이 있는 집행기능의 하위 요소는 무엇 인지 살펴보고자 하였다.

본 연구의 결과는 다음과 같다. 전체적으로 어휘발달지연 아동이 일반아동보다 집행기능과 읽기이해 과제에서 수행능 력이 낮았다. 먼저, 집행기능 과제 중 작업기억 과제(비단어 따라말하기)에서 어휘발달지연 아동은 일반아동보다 통계적 으로 유의하게 낮은 수행을 보였다. 이러한 결과는 어휘발달 지연 아동이 작업기억의 결함으로 인해 언어 처리 과정에서 어려움을 보인다는 많은 선행연구와 일치한다(Alt, 2011; Yim $\&$ Han, 2019). Baddeley (1986)의 다요인 작업기억 모델(multicomponents working memory model)에 따르면, 구어적 작업 기억은 음운 회로(phonological loop)와 중앙 집행기(central executive)의 기능에 의존한다. 음운회로는 언어의 이해에 중 요한 역할을 하는 음운 저장소(phonological short-term store) 와 청각적 시연이 일어나는 곳인 내적 되뇌기 과정(subvocal rehearsal)으로 이루어져 있는데, 이러한 음운회로는 새로운 언 어정보를 장기 기억으로 보내기 전에 짧은 시간동안 유지시 켜주기 때문에 새로운 단어를 습득할 수 있도록 도와주는 요 소로 알려져 있다(Baddeledy, Gathercole, \& Papagno, 1998; S. J. $\mathrm{Kim}, \&$ Choi, 2007). 또한, 중앙 집행기는 언어 정보를 효율적 으로 처리해주는 역할을 하므로 기능 및 용량에 따라 아동의 언어 처리에 영향을 미치는 요소임을 언급하였다(Yim \& Han, 2019). 이를 통해 어휘발달지연 아동이 구어적 작업기억 과 제 시 일반아동에 비해 낮은 수행력을 보였고, 이는 제한된 어 휘 능력을 보이는 데 영향을 미치는 것으로 해석할 수 있다. 억 제 과제(정지신호과제)와 전환 과제(차원전환분류과제)에서 는 어휘발달지연 아동이 일반아동보다 낮은 수행력을 보였으 나, 집단 간 차이는 통계적으로 유의하지 않았다. 이러한 결과 는 억제와 전환 과제에서 두 그룹 간 차이가 나타나지 않은 선 행연구 결과와 일치하나(Marton et al., 2014; Yoo \& Yim, 2018) 어휘발달지연 아동 집단에서 유의한 차이가 나타났다는 선행 연구와는 일치하지 않다(Yang \& Yim, 2018). 집행기능 능력 은 성인기까지 꾸준히 발달하기 때문에 아동이 성장하면서 변 화할 수 있고, 이러한 점으로 인해 연구마다 비일관적인 모습 이 나타난 것으로 해석할 수 있다(Yoo \& Yim, 2018; Zelazo \& Müller, 2002).

둘째, 읽기이해 과제에서 어휘발달지연 아동은 일반아동보 다 통계적으로 유의하게 낮은 수행을 보였다. 이러한 결과는 어휘발달지연 아동이 읽기이해에 어려움을 경험할 가능성이 크고, 어휘 능력이 아동의 읽기이해력을 예측한다는 선행연구
와 일치한다(D. Kim, Cho, Jeong, \& Koh, 2015; D. Kim, Lee, \& Kim, 2019; Oh \& Lee, 2007). 아동은 읽기 자료를 이해하기 위 해 본인의 어휘집에 있는 어휘들을 효율적으로 인출하나, 어 휘발달지연 아동은 제한된 어휘 능력으로 인해 단어, 문장, 문 단의 의미와 흐름을 파악하는 것이 어려워 읽기과제에서 낮은 수행을 보인 것으로 해석된다. 특히 학령기 아동의 어휘력은 읽기이해를 위해 꼭 필요하며 전반적인 학습 상황에서 기초가 되는 요소이다. 그러나 학령전기 아동보다 어휘력의 중요성이 강조되지 않아 중재의 필요성을 간과하기 쉽다. 본 연구 결과 는 학령전기뿐만 아니라 학령기 어휘발달지연 아동에게도 어 휘력 중재가 필요함을 시사한다.

셋째, 집행기능의 하위 요소와 읽기이해 간 상관분석 결과, 일반아동의 경우 집행기능 하위 요소와 읽기이해 과제 수행 간 상관관계가 나타나지 않았고, 어휘발달지연 아동의 경우 집행기능 하위영역 중 작업기억 과제인 비단어 따라말하기와 읽기이해 과제 수행 간 유의한 정적상관관계가 나타났다. 어 휘발달지연 학령기 아동을 대상으로 집행기능과 어휘 능력 간 의 관계를 조사한 연구는 아직 부족하나 일반아동에서 구어적 작업기억 및 전환 능력과 읽기이해 능력 간에 정적상관관계가 나타났고, 어휘발달지연 아동에서 두 과제 간 상관관계가 나 타나지 않았다는 선행연구와는 일치하지 않는다(Yoo \& Yim, 2018). 어휘발달지연 아동의 경우, 일반아동보다 글을 읽고 처 리하는 과정에서 읽기 이해를 위해 필요한 언어 정보를 충분 히 저장할 수 없었으며, 작업기억 용량을 유지하려는 부담이 정보 처리 속도를 감속시키는 결과를 초래한 것으로 해석할 수 있다. Yoo와 Yim (2018)의 연구에 따르면 작업기억 과제 중 하나인 숫자 거꾸로 기억하기에서 어휘 지연 아동이 일반아동 보다 낮은 수행을 보였다. 본 연구에서도 집행기능 하위영역 내에서도 특히 비단어 따라말하기가 다른 과제에 비해 복잡한 언어 처리 과정을 요구하므로 어휘발달지연 아동 집단에서 작 업기억과 읽기이해 간 상관이 나타난 것으로 판단된다. 따라 서 본 연구를 통해 어휘발달지연 아동의 작업기억과 읽기 이 해력 간 높은 관련성이 있는 것으로 해석할 수 있다.

억제 과제와 읽기이해 과제 수행 간에는 두 집단 모두 유의 한 정적상관관계가 나타나지 않았다. 본 연구에서는 억제 능 력을 단일 개념으로 보았으나 최근에는 하위 개념으로 나누 고 있다. 억제는 외부 자극에 대해 우선적이고 자동으로 반응 하는 행동을 억누르는 '행동적 반응 억제 능력'과 현재 수행해 야 과제와 관련 없는 생각이나 정보에 대항하는 '인지적 억제 능력'으로 구성될 수 있다. 이때 행동적 반응 억제 능력은 읽 기 이해와 큰 상관을 보이지 않지만, 인지적 억제 능력은 읽기 
이해와 유창성에서 주된 역할을 한다고 밝혀졌다(Arrington, Kulesz, Francis, Fletcher, \& Barnes, 2014; Christopher et al., 2012). 사전적인 의미 결합만으로 해석하기 어려운 문장은 문 맥을 활용하여 해석해야 하는데, 학령기 일반아동의 경우 이 과정에서 집행기능의 하위 요소 중 하나인 억제 능력이 요구 된다(S. Lee, Kim, Kim, Han, \& Yim, 2019). 그러나 본 연구에 서 시행한 멈춤 신호 과제는 인지적 억제 능력이 아닌 행동적 반응 억제 능력을 측정하는 과제이므로 읽기이해력과의 관계 를 살펴보기에 다소 어려움이 있었던 것으로 보인다. 따라서 후속 연구를 통해 본 연구에서 측정되지 않은 인지적 억제 능 력과 읽기이해 간 상관을 살펴보아 억제와 읽기이해력 간 관 련성을 밝혀낼 수 있기를 기대한다.

전환 과제와 읽기이해 과제 수행 간에도 두 집단 모두 유의 한 정적상관관계가 나타나지 않았다. 이러한 결과는 전환 능 력이 성인기까지 발달하므로 아동의 전환 능력과 읽기 간 관 계를 명확히 밝힐 수 없다는 선행연구와 일치한다(Engel de Abreu et al., 2014). 그러나 읽기에서 어려움을 겪는 아동은 또 래 아동보다 학습규칙이나 주의를 전환하는 데 결함이 있다고 한 선행연구와는 일치하지 않는다(Stoet et al., 2007). 전환 과 제와 읽기이해 과제 수행 간 관련성을 살펴보기 위한 연구과 제의 다양성이 적고 관련 연구가 부족하므로 많은 후속 연구 가 이루어질 필요가 있다.

결론적으로 어휘발달지연 아동은 일반아동보다 구어적 작 업기억 과제에서 더 큰 어려움을 보이는 것으로 나타났다. 이 는 일반아동과 비교하였을 때, 정보처리 시 요구되는 인지능 력이 제한적이라는 것을 의미하며, 일반아동보다 작업기억 용 량이 적고 주의를 집중하여 목표를 달성하고자 하는 집행기능 이 비효율적으로 기능하는 것으로 보인다(Johnston, Smith, \& Box, 1997). 이에 학령기 아동의 어휘 능력 평가 시, 인지능력 평가도 함께 진행할 필요가 있음을 알 수 있다. 특히, 집행기능 과제 중 구어적 작업기억 능력을 확인할 수 있는 비언어 따라 말하기 과제를 함께 실시하는 것이 일반아동과 어휘발달지연 아동을 구별하는 데 도움이 될 것으로 보인다.

후속 연구를 위해 제시하는 본 연구의 한계점과 제언은 다 음과 같다. 첫째, 본 연구에서는 연구대상인 어휘발달지체 아 동 집단을 수용-표현 어휘력 검사의 수용어휘력 결과만을 기 준으로 선별하였다는 점에서 한계가 있다. 수용어휘력은 표현 어휘력과 높은 상관을 보이지만, 수용어휘력 하나만으로는 대 상자의 전반적인 어휘 능력을 예측하기에 어려움이 있다. 따 라서 후속 연구에서는 연구대상의 전반적인 어휘 능력을 평가 하여 어휘력에 따른 집행기능과 읽기이해력의 관계를 강조할
것을 제안한다. 둘째, 본 연구의 연구대상을 경기도 인근 초등 학교 한 곳의 일부 학급에서 선정하였고, 연구대상자 수가 적 었다는 점에서 한계가 있다. 이처럼 인원수와 장소가 제한된 점으로 인해 표본 집단의 대표성이 낮다는 점을 고려하면 본 연구 결과를 전체 학령기 아동으로 일반화하는 것에 어려움이 따르므로 후속 연구에서는 좀 더 세부적으로 조건(예: 연령, 성별 등)을 나누어 많은 수의 표본을 수집하여 집단을 타당하 게 대표할 수 있는 아동을 연구대상자로 선정할 것을 제안한 다. 셋째, 본 연구에서는 억제 능력을 살펴보는 과제를 인지적 반응 억제 능력이 아닌 행동적 반응을 억제하는 능력을 측정 하는 과제로 선정하여 인지적 반응 억제와 읽기이해력 간 상 관관계를 살펴보지 못하였다는 점에서 아쉬움이 남는다. 따라 서 후속 연구에서는 인지적 반응 억제 능력과 읽기이해 간 상 관을 살펴보는 것을 제안한다. 넷째, 본 연구에서 제작한 읽기 이해 검사는 아동의 작업기억 용량에 영향을 미치지 않는 수 준에서 지문 내 정보를 요구하여 읽기이해력을 확인하고자 하 였으나, 다소 암기가 필요한 문항들이 포함되어 있어 읽기이 해 자체만을 평가하기에는 한계가 있다고 판단된다. 이러한 한계점 및 제언을 고려하여 후속 연구가 이루어진다면 학령기 아동의 집행기능과 어휘발달 간 관계, 집행기능과 읽기이해력 간 관계, 어휘발달과 읽기이해력 간 관계를 더욱 명확히 할 수 있을 것이며, 학령기를 넘어 다른 연령층에서도 이러한 능력 간의 관계를 알아보는 연구를 진행할 때 참고할 수 있을 것으 로 판단된다. 이러한 한계점 및 제언을 고려하여 후속 연구가 이루어진다면 학령기 아동의 집행기능과 어휘발달 간 관계, 집행기능과 읽기이해력 간 관계, 어휘발달과 읽기이해력 간 관계를 더욱 명확히 할 수 있을 것이며, 학령기를 넘어 다른 연 령층에서도 이러한 능력 간의 관계를 알아보는 연구를 진행할 때 참고할 수 있을 것으로 사료된다.

\section{Acknowledgements}

This work was supported by the Ministry of Education of the Republic of Korea and the National Research Foundation of Korea (NRF-2018S1A3A2075274).

\section{Conflict of Interest}

No potential conflict of interest relevant to this article was reported. 


\section{Ethics Statement}

All procedures of this research were reviewed by IRB (ewha201910-0022-01).

\section{References}

\section{In English}

Alt, M. (2011). Phonological working memory impairments in children with specific language impairment: Where does the problem lie? Journal of Communication Disorders, 44(2), 173-185. doi:10.1016/j.jcomdis.2010.09.003

Arrington, C. N., Kulesz, P. A., Francis, D. J., Fletcher, J. M., \& Barnes, M. A. (2014). The contribution of attentional control and working memory to reading comprehension and decoding. Scientific Studies of Reading, 18(5), 1-59. doi :10.1080/10888438.2014.902461

Baddeley, A. (1986). Working memory. Oxford, GB: Clarendon Press.

Baddeley, A., Gathercole, S., \& Papagno, C. (1998). The phonological loop as a language learning device. Psycholocial Review, 105(1), 158-173.

Borella, E., \& de Ribaupierre, A. (2014). The role of working memory, inhibition, and processing speed in text comprehension in children. Learning and Individual Differences, 34, 86-92. doi:10.1016/j.lindif.2014.05.001

Carretti, B., Borella, E., Cornoldi, C., \& De Beni, R. (2009). Role of working memory in explaining the performance of individuals with specific reading comprehension difficulties: A meta analysis. Learning and Individual Differences, 19, 246-251. doi:10.1016/j.lindif.2008.10.002

Catts, H. W. (2009). The narrow view of reading promotes a broad view of comprehension. Language, Speech, and Hearing Services in Schools, 40(2), 178-183. doi:10.1044/0161-1461 (2008/08-0035)

Catts, H. W., \& Kamhi, A. G. (2005). Language and reading disabilities (2nd ed). Boston, MA: Allyn \& Bacon.

Christopher, M. E., Miyake, A., Keenan, J. M., Pennington, B., DeFries, J. C., Wadsworth, S. J.,...Olson, R. K. (2012). Predicting word reading and comprehension with executive function and speed measures across development: A latent variable analysis. Journal of Experimental Psychology: General, 141(3), 470-488. doi:10.1037/a0027375

Dehaene, S. (2009). Reading in the brain: The new science of how we read. New York: Penguin.

Diamond, A. (2006). The early development of executive functions. Lifespan Cognition: Mechanisms of Change, 210,
70-95.

Diamond, A. (2013). Executive functions. Annual Review of Psychology, 64, 135-168. doi:10.1146/annurev-psych113011-143750

Dollaghan. C., \& Campbell, T. F. (1998). Nonword repetition and child language impairment. Journal of Speech, Language, and Hearing Research, 41(5), 1136-1146. doi:10.1044/jslhr. 4105.1136

Engel de Abreu, P. M. J., Puglisi, M. L., Cruz-Santos, A., Befi-Lopes, D. M., \& Martin, R. (2014). Effects of impoverished environmental conditions on working memory performance. Journal of Memory, 22(4), 323-331. doi:10.1080/09658211.2013.781186

E-Prime (Version 2.0). [Computer software]. Pittsburgh, PA: Psychology Software Tools Inc.

Garon, N., Bryson, S. E., \& Smith, I. M. (2008). Executive function in preschoolers: A review using an integrative framework. Psychological Bulletin, 134(1), 31-60. doi:10. 1037/0033-2909.134.1.31

Gathercole, S. E., \& Baddeley, A. D. (1990). Phonological memory deficits in language disordered children: Is there a causal connection? Journal of Memory and Language, 29(3), 336360. doi:10.1016/0749-596X(90)90004-J

Gernsbacher, M. A., \& Faust, M. E. (1991). The mechanism of suppression: a component of general comprehension skill. Journal of Experimental Psychology: Learning, Memory, and Cognition, 17, 245-262. doi:10.1037/0278-7393.17.2.245

Henry, L. A., Messer, D. J., \& Nash, G. (2012). Phonological and visuospatial short-term memory in children with specific language impairment. Journal of Cognitive Education and Psychology, 11(1), 45-56. doi:10.1891/1945-8959.11.1.45

Hughes, C. (1998). Executive function in preschoolers: Links with theory of mind and verbal ability. British Journal of Developmental Psychology, 16(2), 233-253. doi:10.1111/j. 2044-835X.1998.tb00921.x

Johnston, J. R., Smith, L. B., \& Box, P. (1997). Cognition and communication: Referential strategies used by preschoolers with specific language impairment. Journal of Speech, Language, and Hearing Research, 40(5), 964-974. doi:10.1044/jslhr.4005.964

Just, M. A., \& Carpenter, P. A. (1992). A capacity theory of comprehension: Individual differences in working memory. Psychological Review, 99, 122-149. doi:10.1037/0033295X.99.1.122

Klein, G. S. (1964). Semantic power measured through the interference of words with color-naming. The American Journal of Psychology, 77(4), 576-588. doi:10.2307/1420768

Marton, K., Campanelli, L., Eichorn, N., Scheuer, J., \& Yoon, J. (2014). Information processing and proactive interference in children with and without specific language impairment. Journal of Speech, Language, and Hearing Research, 57(1), 
106-119. doi:10.1044/1092-4388(2013/12-0306)

Mazuka, R., Jincho, N., \& Oishi, H. (2009). Development of executive control and language processing. Language and Linguistics Compass, 3(1), 59-89. doi:10.1111/j.1749-818X. 2008.00102.x

Miyake, A., Friedman, N. P., Emerson, M. J., Witzki, A. H., Howerter, A., \& Wager, T. D. (2000). The unity and diversity of executive functions and their contributions to complex "frontal lobe" tasks: A latent variable analysis. Cognitive Psychology, 41(1), 49-100. doi:10.1006/cogp. 1999.0734

Montgomery, J. W. (2002). Understanding the language difficulties of children with specific language impairments: Does verbal working memory matter?. American Journal of SpeechLanguage Pathology, 11(1), 77-91. doi:10.1044/1058-0360 (2002/009)

Montgomery, J. W., \& Windsor, J. (2007). Examining the language performances of children with and without specific language impairment: Contributions of phonological shortterm memory and speed of processing. Journal of Speech, Language, and Hearing Research, 50(3), 778-797. doi:10. 1044/1092-4388(2007/054)

Munson, B., Kurtz, B. A., \& Windsor, J. (2005). The influence of vocabulary size, phonotactic probability, and wordlikeness on nonword repetitions of children with and without specific language impairment. Journal of Speech, Language, and Hearing Research, 48, 1033-1047. doi:10.1044/10924388(2005/072)

Nouwens, S., Groen, M. A., \& Verhoeven, L. (2016). How storage and executive functions contribute to children's reading comprehension. Learning and Individual Differences, 47, 96-102. doi:10.1016/j.lindif.2015.12.008

Ouellette, G. O. (2006). What's meaning got to do with it: The role of vocabulary in word reading and reading comprehension. Journal of Educational Psychology, 98(3), 554-566. doi:10.1037/0022-0663.98.3.554

Stanovich, K. E. (1986). Matthew effects in reading: Some consequences of individual differences in the acquisition of literacy. Reading Research Quarterly, 21(4), 360-407.

Stoet, G., Markey, H., \& López, B. (2007). Dyslexia and attentional shifting. Neuroscience Letters, 427(1), 61-65. doi:10.1016/j.neulet.2007.09.014

Vaughn, S., Gersten, R., \& Chard, D. J. (2000). The underlying message in LD intervention research: Findings from research syntheses. Exceptional Children, 67(1), 99-114. doi: $10.1177 / 001440290006700107$

Wilson, S. P., \& Kipp, K. (1998). The development of efficient inhibition: Evidence from directed-forgetting tasks. Developmental Review, 18(1), 86-123. doi:10.1006/drev. 1997.0445
Zelazo, P. D., \& Müller, U. (2002). Executive function in typical and atypical development. In U. Goswami (Ed.), Handbook of childhood cognitive development (pp. 445-469). Oxford, GB: Blackwell. doi:10.1002/9780470996652.ch20

\section{In Korean}

Chung, B. J. (2011). Relationships among word recognition, reading comprehension, phonological awareness, working memory, listening comprehension, and inferential skills: A two-year longitudinal study of second and third graders. Journal of Speech-Language \& Hearing Disorders, 20(1), 103-121.

Kim, A. H. (2013). A comparison of elementary students with reading disabilities to students without disabilities on vocabulary performance and error patterns. The Korea Journal of Learning Disabilities, 10(1), 51-67.

Kim, D., Cho, Y., Jeong, S., \& Koh, H. (2015). A multilevel metaanalysis of vocabulary intervention for students with and without learning difficulties and students with learning disability. Korean Journal of Special Education, 50(1), 121145.

Kim, D., Lee, J., \& Kim, H. (2019). Analysis of vocabulary and reading comprehension abilities of elementary school 6th grade students using the latent class model. Journal of Special Education for Curriculum and Instruction, 12(1), 2744. doi:10.24005/seci.2019.12.1.27

Kim, Y., Hong, G., Kim, K., Jang, H., \& Lee, J. (2009). Receptive \& expressive vocabulary test (REVT). Seoul: Seoul Community Rehabilitation Center.

Kim, J. L., Kang, E. H., \& Lee, J. Y. (2018). The effects of phonological awareness intervention program on the phonological awareness and word recognition ability in children with intellectual disabilities. Journal of SpeechLanguage \& Hearing Disorders, 27(3), 1-12.

Kim, S. J., \& Choi, Y. H. (2007). Effects of phonological shortterm memory, learning styles, and oral repetition on middle school students' learning of English vocabulary. Foreign Languages Education, 14(1), 243-270.

Oh, H. J., \& Lee, Y. K. (2007). Reading ability of korean lower graders with specific language impairment. Journal of Speech-Language \& Hearing Disorders, 16(4), 61-74.

Hwang, M. (2014). Working memory of children with reading comprehension difficulty: Sentence repetition and nonword repetition. The Korea Journal of Learning Disabilities, 11(1), 53-72.

Lee, H. J. (2010). The influences of number of syllables and wordlikeness on 3-to 5-year-old Korean-English bilingual children's nonword repetition (Master's thesis). Retrieved from http://www.riss.kr/link?id=T11929916 
Lee, S., Kim, H., Kim, T., Han, J., \& Yim, D. (2019). Comparison of idiom comprehension ability and its relationship to executive functions in school-aged children with and without vocabulary delay. Journal of Educational Research, 57(4), 215-246. doi:10.30916/KERA.57.4.215

Yang, Y., Yim, D., \& Bae, K. (2015). Predictors of word learning in children with specific language impairment. Communication Sciences \& Disorders, 20(1), 1-12. doi:10.12963/csd.14176

Yang, Y., Yim, D., Kim, S., \& Han, J. (2013). The relationship among receptive vocabulary, non-word repetition, and quick incidental learning in preschoolers with and without delay in vocabulary development. Communication Sciences \& Disorders, 18(4), 379-391. doi:10.12963/csd.13079

Yang, Y., \& Yim, D. (2018). The role of executive function for vocabulary acquisition and word learning in preschool-age children with and without vocabulary delay. Communication Sciences \& Disorders, 23(1), 43-59. doi:10.12963/csd.18469

Yim, D., \& Han, J. (2019). Phonological loops, visuospatial sketchpad, episodic buffers, and inhibition in children with a language delay. Korean Journal of Special Education, 54(2), 183-204. doi:10.15861/kjse.2019.54.2.183

Yoo, J., \& Yim, D. (2018). Relationship among executive functions, vocabulary and reading skills in school-aged children with and without poor vocabulary. Communication Sciences \& Disorders, 23(3), 570-583. doi:10.12963/csd. 18523

Yoon, H. (2019). Word reading, reading fluency, and reading comprehension of first graders with and without vocabulary delay. Journal of Learner-Centered Curriculum and Instruction, 19(18), 143-158. doi: 10.22251/jlcci.2019.19.18.143

\section{ORCID}

Jieun Kang http://orcid.org/0000-0002-9438-2147 Hyojung Kwak http://orcid.org/0000-0002-1704-5278

Hyejo Kim http://orcid.org/0000-0002-9327-8866

Minah Yoo http://orcid.org/0000-0002-4210-5391

Dongsun Yim http://orcid.org/0000-0001-8254-9504

Received December 31, 2019 Revision received February 20, 2020

Accepted March 26, 2020 


\section{Appendix 1}

Reading materials and questionaires

\section{나의 가장 친한 친구, 미호}

연아와 미호는 가장 친한 친구였습니다. 2 학년 때 미호가 옆집으로 이사 온 이후로 방과 후 거의 매 일 같이 놀았습니다.

연아는 학교에서 숙제를 열심히 하고, 많은 책을 읽었고, 발레 수업을 들었습니다. 반면에 미호는 학 업보다 축구를 즐기고 학교에서 다른 친구들과 이야기하는 것을 더 좋아하였으며, 책의 한 단원을 거의

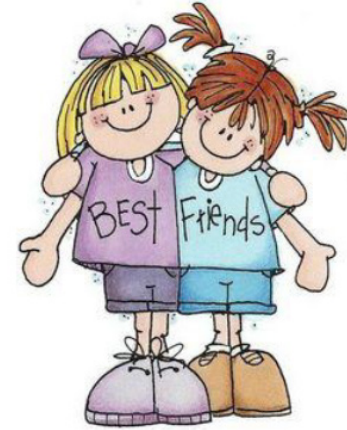
다 읽지도 않았습니다.

연아와 미호는 종종 길 건너 공원에서 함께 놀았습니다. 두 친구는 장난 감을 가지고 놀거나, 동네 친구들과 축구를 하거나 술래잡기를 하였습니 다. 밖에 비가 내릴 땐, 두 친구는 집에서 공예품을 만들거나, 비디오 게임 을 하였습니다. 두 친구는 어떤 날에는 아무 문제 없이 많은 시간을 보낼 수 있었지만, 어떤 날에는 무엇을 할지에 대해 싸우기도 했습니다.

“오늘은 장난감 가지고 놀자. 우리 3일 동안 축구만 했어!”라고 연아가 말했습니다.

"나는 장난감을 가지고 놀기보다는 축구를 하고 싶어."라고 미호가 대답했습니다.

“우리는 놀 때 왜 맨날 네가 하고 싶은 것만 해? 이제 내가 좋아하는 것도 했으면 좋겠어."라고 연아 가 말했지만, 미호는 “좋아, 너 혼자 장난감 가지고 놀아! 나는 축구 할게!”라고 소리쳤습니다.

연아는 화가 나서 집으로 가버렸습니다. 연아가 집에 돌아왔을 때, 자신이 미호의 공책을 가지고 있 다는 것을 깨달았습니다. '오늘은 이걸 돌려주지 않을 거야. 미호 진짜 미워!'

다음날 학교에서 선생님이 숙제 검사를 했습니다. 미호는 숙제를 한 공책이 없어서 선생님께 내일 숙제 검사를 받아도 되는지 여쭈어보았습니다. 선생님은 " .”라고 말씀하셨습니 다. 미호는 화가 나서 조용히 자리로 돌아갔습니다. 연아는 선생님께 미호의 공책을 자신이 가지고 있 다고 말해야 한다는 것을 알았지만, 고민이 되었습니다.

결국 점심시간에 연아는 선생님을 찾아갔습니다.

"선생님, 제가 미호 공책을 가지고 있어요. 더 일찍 말했어야 했는데 어제 미호와 싸웠고, 아직 화해 하지 못했어요. 우리가 화해할 수 있도록 도와주세요."라고 연아가 말했습니다.

선생님은 "연아야, 솔직하게 말해주어서 고마워. 선생님에게 도움을 요청하다니 기쁘구나."라고 말 씀하셨습니다.

쉬는 시간에 선생님은 두 친구에게 이야기했습니다. "연아야, 미호야. 친한 친구라고 해서 매일 같이 놀 필요는 없단다. 매일 같이 놀지 않아도 친한 친구가 될 수 있어.” 


\section{나의 가장 친한 친구, 미호}

이름 :

(남/여)

학 년 :

번호:

1. 미호는 언제 연아의 옆집으로 이사를 왔나요?

2. 비가 올 때 연아와 미호는 무엇을 하며 놀았나요?

3. 연아는 미호의 무엇을 가지고 있었나요?

4. 미호는 왜 선생님께 숙제를 낼 수 없었나요?

5. 연아와 미호는 왜 싸웠나요?

6. 연아는 선생님을 왜 찾아갔나요?

7. 숙제를 낼 수 없다는 미호의 말에 선생님은 뭐라고 말씀하셨나요?

8. 숙제 검사를 받지 못한 미호를 보며 연아는 속으로 무슨 생각을 하였을까요?

9. 선생님의 조언을 들은 연아와 미호는 어떻게 되었을까요?

10. 이야기가 얼마나 어려웠나요?(어렵다고 생각하는 만큼 색칠해 주세요.)

\begin{tabular}{|l|l|l|l|l|l|l|l|l|}
\hline & & & & & & & & \\
\end{tabular}




\section{‘애완동물과 함께 등교’하는 날의 재앙}

‘애완동물과 함께 등교' 하는 날에 나는 가방을 메고 손에 목줄을 들고 있었습니다. 나는 강아지 짱아와 버스정류장으로 즐겁게 걸어갔습니다. 동네 친구들도 애완동물을 키웠습니다. 수지는 물고기 니모가 사 는 어항을 들고 있었습니다. 석진이는 그의 고양이 키티가 있는 상자를 들고 있었습니다. 시원이는 잉꼬 쑥쑥이가 있는 새장을 가지고 있었습니다. 우리는 모두 애완동물을 데리고 와서 신이 났습니다.

하지만 우리가 버스에 올라타고 내리막길에 접어들면서, 문제가 생기기 시작했습니다. 친구들은 떠들 고, 동물들이 시끄러운 울음소리를 내서 버스가 너무 시끄러웠습니다. 짱아는 여기저기 냄새를 맡느라, 나 와 함께 자리에 앉으려고 하지 않습니다. 우리가 자리에 앉았을 때, 다른 개가 뒤에서 갑자기 우리에게 달 려왔습니다. 그 개와 짱아는 서로 냄새를 맡고, 놀기 시작했습니다.

"초코! 돌아와!" 3학년 학생 중 한 명이 소리쳤습니다. 개는 목소리가 들리는 쪽으로 달려갔습니다. "버 스 여기저기를 뛰어다니게 하는 것은 위험하니까 각자 애완동물 잘 데리고 있으세요."라고 버스 운전사가 말했습니다. 마침내, 우리는 학교에 도착했습니다. 그리고 나서, 나는 학교 운동장을 보았습니다.

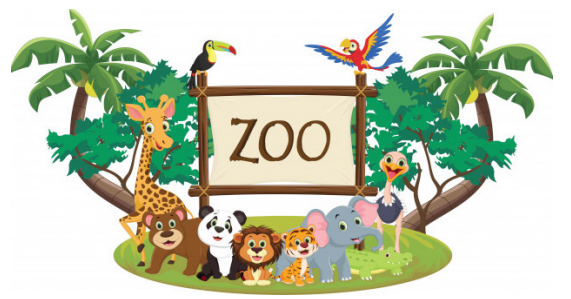

학교는 마치 동물원 같았습니다! 사방에 모든 종류와 크기의 개, 새장 속의 형형색색 새, 토끼, 친칠라, 고슴도치 등이 있었습 니다. 그리고 어떤 동물들은 잔디밭과 보도 위를 자유롭게 뛰어 다녔고, 친구들은 동물들을 사방으로 쫓아다녔습니다.

잔디 위에 애완동물들의 물건이 널브러져 있었고, 공중에는 털이 날아다녔습니다. 나는 '학교 밖이 이 렇게 심한데, 학교 안은 더 심할 거야라고 생각했습니다.

그때, 나는 잔디에서 깡충깡충 뛰는 캥커루와 계단을 뛰어오르는 공작새도 보았습니다. 나는 교실로 걸 어 들어갔습니다. 복도는 버스보다 냄새가 더 지독했습니다. 사방에 여전히 동물들이 마구 뛰어다니고, 엉 망진창이었습니다. 교실 안에는 훨씬 더 심했습니다. 선생님은 수업시간에 애완동물들을 책상에 묶어두 라고 지시하였습니다. 그런데 갑자기 선생님이 말을 하다가 갑자기 앵무새로 변하기 시작하였습니다.

그리고 나는 잠자리에서 황급히 일어났습니다. 그리고 나는 학교에 '애완동물과 함께 등교'하는 날이 없는 것이 다행이라고 생각했습니다. 


\section{‘애완동물과 함께 등교’하는 날의 재앙}

이름:

(남/여)

학 년 :

번호:

1. 학교에 볼 수 있었던 동물을 적으세요. (4가지 이상)

2. 짱아가 버스에서 앉지 않은 이유는 무엇일까요?

3. 선생님이 무엇으로 변했나요?

4. 버스에서 갑자기 달려온 개의 주인은 누구일까요?

5. 시원이가 쑥쑥이를 들고 학교에 온 이유는 무엇일까요?

6. 운동장이 엉망진창인 이유는 무엇일까요?

7. 운동장보다 교실 안이 더 심각했던 이유는 무엇일까요?

8. 잔디 위에 어떤 물건들이 널브러져 있었을까요? (2가지 이상)

9. 주인공이 "애완동물 데리고 학교 가는 날"이 없어서 다행이라고 한 이유는 무엇일까요?

10. 이야기가 얼마나 어려웠나요?(어렵다고 생각하는 만큼 색칠해 주세요.)

\begin{tabular}{|l|l|l|l|l|l|l|l|l|}
\hline & & & & & & & & \\
\end{tabular}

